\title{
THE EFFECTIVENESS OF SOCIAL ASSISTANCE IN THE DEVELOPMENT OF HUMAN RESOURCES IN BINA SIWI 2018-2020
}

\author{
Herpita Wahyuni ${ }^{1^{*}}$, Zuly Qodir ${ }^{1}$ \\ ${ }^{1}$ Universitas Muhammadiyah Yogyakarta, Indonesia \\ *e-mail: herpitawahyuni@yahoo.com
}

\begin{abstract}
This study aims to determine the use of social assistance at the Bina Siwi Orphanage, which focuses on developing human resources. The data analysis used qualitative research methods from the results of the library study and the effects of interviews, and then the data was processed with the help of NVivo 12 Plus software with the Crosstab Query, World Cloud feature so that from the data obtained a score that can be assessed for its effectiveness in the utilization of human resource development. This research focuses on the Bina Siwi Orphanage in utilizing social assistance. The study results can be concluded that social service has been carried out well and has been effective. The development of human resources at the orphanage can meet the needs of daily life, such as three meals a day, school education, skills development, and health insurance. Furthermore, the study results positively impact other institutions in the management of social assistance to advance human resources.
\end{abstract}

Keywords: Effectiveness; Social Assistance; Human Resources

This is an open access article under the CC BY-SA license.

Copyright (C) 2021 by Author. Published by Universitas Pendidikan Ganesha.

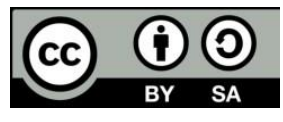

\section{INTRODUCTION}

A nation wants to achieve progress and considers that education is one of the primary needs and cannot be separated from basic needs, namely the need for food, clothing, and housing (Hasan et al., 2017). The development of a nation is a dynamic and multidimensional process to achieve higher social welfare, including various fundamental changes to the social structure and national institutions while continuing to pursue accelerated economic growth, handling income inequality, and alleviating poverty (Wirawan, 2015). The problem of poverty is a challenge faced by the government from time to time; poverty is a complex problem that requires special handling and programs (Hasan et al., 2017).

Poverty from the point of view of political issues, that poverty is caused by wrong political policies in giving birth to social injustice and weak opportunities to obtain education (Sulaeman, 2018). The young generation is an essential asset for the future, which of course must get protection from various parties, from the smallest to the state scope; child protection is an activity to guarantee and protect the right to live and develop and be protected from discrimination (Marpaung \& Hulu, 2019). The problem faced in the current global era is the limited quality of human resources and is involved in the 
implementation of development (Kementrian Sosial, 2018).

Human resource development requires an approach that is a form of alternative product that requires the community to be independent in meeting their needs (Kementrian Sosial, 2018). Fulfilling the necessities of life by providing social assistance to groups or groups is a form of social concern in creating a competitive society (Nuskhiya Asfi, 2015). Community empowerment will offer opportunities for a more independent and prosperous life (Hanifah, 2020).

Orphanages are institutions that fulfill the welfare of abandoned children that provide a place to replace services as parents in meeting their needs and are expected to become a generation for the nation (Akbar \& Gunawan, 2016). The presence of an orphanage-based service institution that was established is an alternative in solving the problem of meeting the needs of children and various other rights (Setiyawati et al., 2018). Orphanages are institutions that provide solutions in handling neglected children, children who do not have access to education and protection such as health services, and the fulfillment of food and clothing ( Dede et al., 2020). The orphanage will provide coaching and talent development to provide work amid society (Muskhir, 2019). The orphanage's caretaker acts as a substitute for parents who will give advice, try to be a good friend without dissecting one another, and have high empathy (Roja, 2020).

Human resource development is expected to create a young generation with high competitiveness and is likely to contribute to society (Cahyani, 2017). Quality resources will provide progress and social equality in obtaining rights and obligations (Roja, 2020). An organization needs reliable human resources to support the achievement of a goal. Human resources must move effectively and efficiently to obtain good usability results
(Setiawan, 2016). Human resource development is a positive activity that can improve work ethic with a skills training process (Irwandi, 2017).

Bina Siwi Orphanage is an orphanage that protects neglected children located in Sendangsari Village, Pajangan, Bantul, Yogyakarta, which provides social services and creative skills development (Afriansyah \& Santoso, 2020). Human resource development cannot be separated from various assistance and support from various related social institutions (Khaira et al., 2017). Different social received aid will impact progress in human resource development (Sunarsi, 2018). Practical social assistance will support success in managing human resources and creating social justice (Akbar \& Gunawan, 2016). Bina Siwi Orphanage residents who have limitations are aspects or require more attention in developing resources (Afriansyah \& Santoso, 2020).

Various literature makes the importance of human resources in obtaining the quality of a creative society. Therefore, research on the effectiveness of social assistance in developing human resources at the Bina Siwi Orphanage needs to be researched. The reason for choosing the research location at the Bina Siwi Orphanage, an orphanage that is active in receiving social assistance, is that the results of its management in terms of utilization and development of human resources can be studied.

\section{METHODS}

This study uses descriptive qualitative research methods with data sources, namely, primary data obtained directly from interviews with the management of the Bina Siwi Orphanage and a library study by describing and analyzing the findings in detail (Creswell, 2018). The effectiveness of social assistance in developing human resources at the Bina Siwi Orphanage by measuring

Jurnal IImu Sosial dan Humaniora| 217 
the use of social assistance through the fulfillment of education, protection of health services, and the fulfillment of food and clothing (Dede et al., 2020). Data analysis using NVivo 12 plus software with data collected from interviews and library studies taken in response to research results. The data is processed with the crosstab feature to automatically calculate the necessary main statistical tests with meaningful comparisons and analysis of indirect variables (Zamawe, 2015). A part of Crosstab Query is to enter code (manual, generated, etc.), text data, and numeric data in variables and pattern data. At this stage, an automatic calculation was found between all related data on the effectiveness of social assistance in developing human resources at the Bina Siwi Orphanage by measuring the use of social assistance through the fulfillment of education, protection of health services, and the fulfillment of food and clothing (Dede et al., 2020).

Human resource development at the Bina Siwi Orphanage is located in Sendangsari Village, Pajangan, Bantul, Yogyakarta. This orphanage contains children with special needs who certainly do not deserve to have their rights ignored and the need to develop resources for a more decent, sustainable life. Using the Word Cloud feature, find frequently occurring words from data findings or display often discussed terms. The data are supported by results from various literature of previous studies that can strengthen research on the effectiveness of social assistance in developing human resources at the Bina Siwi Orphanage.

\section{RESULTS AND DISCUSSION}

Human resource development is a positive activity that can improve work ethic with a skills training process (Irwandi, 2017). Institutions based on established orphanages are an alternative in solving the problem of meeting the needs of children and various other rights (Setiyawati et al., 2018). The development of a nation is a dynamic and multidimensional process to achieve higher social welfare, including various fundamental changes to the social structure and national institutions while continuing to pursue accelerated economic growth, handling income inequality, and alleviating poverty (Wirawan, 2015). Fulfilling the life needs of orphanage children cannot be separated from social assistance and other institutions (Vandenbroucke et al., 2017). Orphanages are institutions that fulfill the welfare of abandoned children that provide a place to replace services as parents in meeting their needs and are expected to become a generation for the nation (Akbar \& Gunawan, 2016).

Effectiveness is achieving agreed goals and objectives to achieve common business goals (Putri Diah Qashdinad, 2018). Various sources of aid funds received by the Bina Siwi Orphanage are utilized to the maximum extent possible, hoping that the same rights and obligations will be fulfilled. The results of interviews with nursing home administrators in using social assistance in human resource development can be assessed through the fulfillment of education and protection, such as health services and the completion of food and clothing (Dede et al., 2020). The interview data was processed with the help of the NViv0 12 Plus software by using the Crosstab Query feature and obtaining a score from the indicator, which will be detailed in Figure 1. 


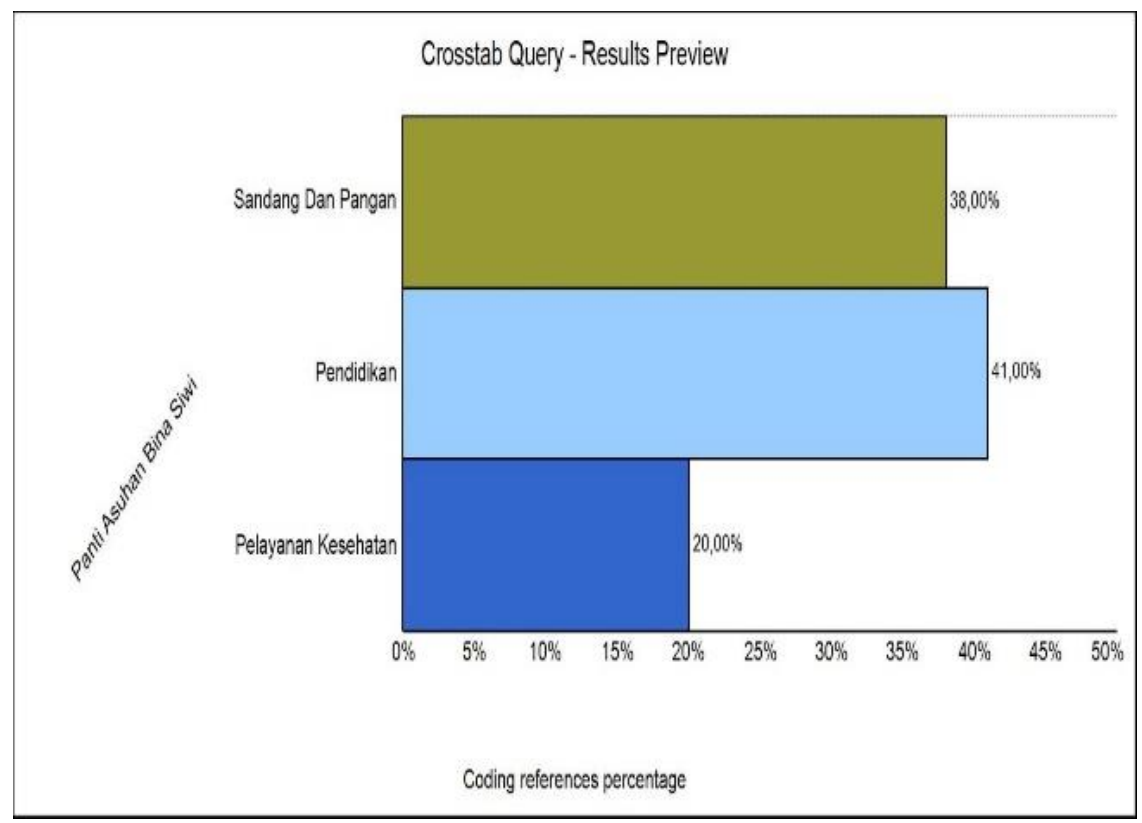

Figure 1. Results of HR development (Data processed with NVivo 12 Plus, 2020)

Social assistance assists in the form of money/goods from local governments to individuals, families, groups, and communities that are not continuous and selective, which aims to protect against possible social risks (Samsudin, 2019). Social assistance can meet food needs and provide more balanced nutrition, on target and on time (Ristyawati, 2020). The provision of social service can be used effectively to develop human resources (Kurniawan, 2015). The form of distribution of social assistance can be used in the aspect of fulfilling education development resources (Vampa, 2017).

Education is the central aspect of creating competent human resources (Sitepu, 2016). Every community has the same opportunity to meet educational needs without distinguishing one another (Barany et al., 2020). People with disabilities are involved in national development, so they need to get attention and be utilized as well as possible; people with disabilities have the same rights and positions as other people (Abdulazis, 2017). The orphanage will provide coaching and talent development to provide work amid society (Muskhir, 2019).

The development of human resources on the Education indicators obtained by the children of the Bina Siwi Orphanage from the social assistance funds received was put to good use, resulting in data analysis with the Crosstab Query feature NVivo 12 Plus obtained a score of $41.00 \%$. The data show a high value in utilizing human resources. Sources of social assistance are obtained from volunteers, donors, community members, institutions, traditional leaders, and social services. Social aid is in the form of money, necessities, motorbikes, and necessary tools. The various aids are used for activities in increasing human resources, namely through formal education and non-formal education. The Bina Siwi Orphanage accommodates 38 persons with disabilities, with 22 women and 16 men. In addition, 
there are 34 children with mental retardation, one person who is speech impaired, one visually impaired person, and 3 children with disabilities. The funds obtained from various donors have been put to good use by the orphanage. In this case, of the 38 children, nine are of school age and currently studying at school, and 29 of the other children are receiving training or non-formal education. According to their respective interests so that they are channeled effectively in the field of education.

Activities undertaken to achieve human resource development from the grants are Art training in playing angklung and gamelan music, making paintings, batik making, making hotel slippers, dolls, pillows, wallets, and making fans. Residents of the orphanage very effectively carry out these activities; various non-formal activities through these training can produce helpful work and generate money to meet daily needs. The implementation of education at this orphanage has been carried out well in the development of human resources. The orphanage's caretaker acts as a substitute for parents who will give advice, try to be a good friend without dissecting one another, and have high empathy (Roja, 2020).

Human resource development is supported by fulfilling basic needs for every human being, consisting of clothing, food, and shelter needs (Nica Cahyani, 2017). Human resource development is expected to create a young generation with high competitiveness and is likely to contribute to society (Cahyani, 2017). The fulfillment of clothing and food needs will provide a sense of security in social life (Rahim, 2019). Pride of clothing and food at Bina Siwi Orphanage from the results of the NVivo analysis obtained a pretty good score of $38.00 \%$. The data shows that the fulfillment of clothing and food has been distributed properly. The beginning of the Bina Siwi Orphanage establishment was when Mr. Sugiman, a volunteer contracted by the Social Service of the Special Region of Yogyakarta. Mr.
Sugiman saw the reality on the ground that there was no one with disabilities to accommodate and accompany them. Mr. Sugiman and the other volunteers moved modestly, but the positive response came from various people and was supported by the Social Service. And finally cooperated with the community.

The establishment of this orphanage since 1989 until now stands on the land of the upper village and is ready to provide services and empowerment to children with disabilities or disabilities. The funds received are used to meet food needs to meet adequate nutrition. The children of the Bina Siwi Orphanage are fed three times a day, namely: breakfast, lunch, and dinner. Assessment of clothing and food fulfillment from social assistance has been running effectively for a decent life and dignity of daily needs. The administrators assist and provide unique approaches to make them comfortable and safe to feel at home in the orphanage and develop their abilities. Fulfilling the necessities of life by providing social assistance to groups or groups is a form of social concern in creating a competitive society (Nuskhiya Asfi, 2015).

The young generation is an essential asset for the future, which of course must get protection from various parties, from the smallest to the state scope; child protection is an activity to guarantee and protect the right to live and develop and be protected from discrimination which is cooperation in social welfare (Marpaung \& Hulu, 2019). Moreover, social welfare can be seen from the aspect of concern for the environmental situation of people who have limitations in meeting economic, educational, and health needs (Setiyawati et al., 2018).

Social assistance in fulfilling public health is the right of every community to access adequate health (Roja, 2020). Fulfilling the need for access to health is a form of community social justice (Setiyawan, 2019). Fulfillment of the right to obtain health services is the right of every Indonesian

Jurnal IImu Sosial dan Humaniora| 220 
citizen. The benefits received by the children of the Bina Siwi Orphanage got an analysis result of $20.00 \%$. The children of the Bina Siwi Orphanage have access to reasonably good health care when the sick children of the orphanage are treated for free at the nearest public health center. Orphanage children have savings from the results of their creativity so that when they are urgent or sick, they can use their savings or social assistance funds for treatment if they are seriously ill or need special handling. Health Services at the Bina Siwi Orphanage have been implemented quite well, and there is a need to improve the quality of services and sensitivity to the quality of health.

The effectiveness of social assistance in the development of human resources at the Bina Siwi Orphanage in 2018-2020 from the results of the World Cloud NVivo 12 Plus analysis found the most popular words from the study which were the findings of research that provided an overview of the implementation in the use of social assistance. In human resource development. The analysis results found the ten most famous words in the discussion on the effectiveness of social service in human resource development, as shown in Table 1.

Table 1. World Cloud Data

\begin{tabular}{|l|r|r|r|}
\hline Word & Length & Count & Weighted Percentage (\%) \\
\hline orphanage & 5 & 76 & 002 \\
\hline development & 12 & 70 & 002 \\
\hline source & 6 & 65 & 001 \\
\hline social & 6 & 59 & 001 \\
\hline disability & 11 & 56 & 001 \\
\hline power & 4 & 55 & 001 \\
\hline human & 7 & 53 & 001 \\
\hline research & 10 & 52 & 001 \\
\hline siwi & 4 & 48 & 001 \\
\hline bina & 4 & 46 & 001 \\
\hline
\end{tabular}

Source: (NVivo 12 Plus Analyisis, 2020)

The data in Table 1 are data from the NVivo 12 Plus analysis results, which raises the most frequently discussed words about the effectiveness of social assistance in developing human resources at the Bina Siwi Orphanage. The World Cloud data analysis results found the ten most famous words in discussing social service points in developing human resources at the Bina Siwi Orphanage: orphanage, development, resources, social, disability, resource, human, research, siwi, and bina. Various discussion activities from the findings are a form of synchronization of research results in social assistance sources in human resource development. The World Cloud NVivo 12 Plus feature from the discussion results brought up the fifty most discussed words, which can be seen in Figure 2. 


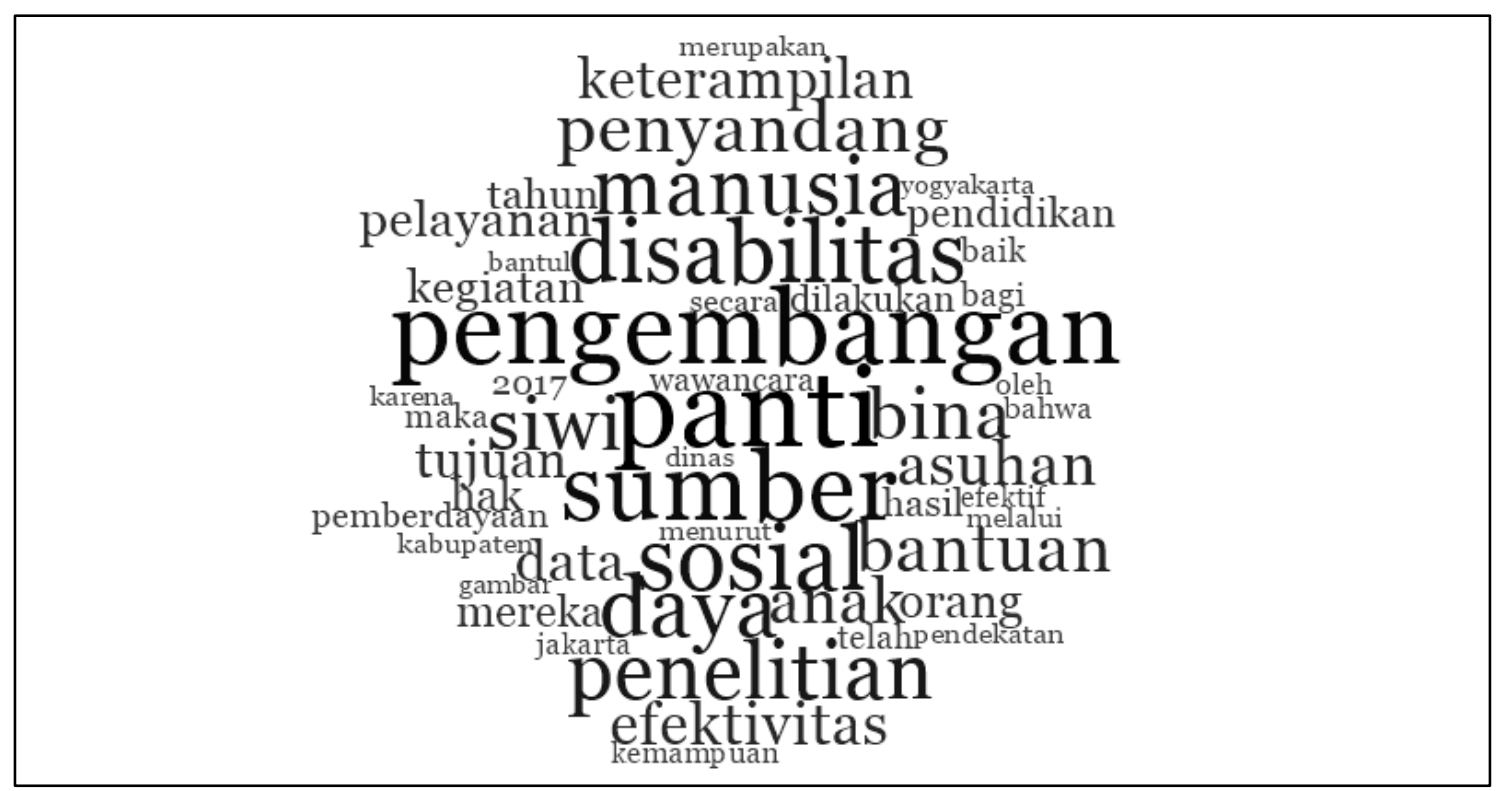

Source: (NVivo 12 Plus, 2020)

The words that most often appear from the World Cloud NVivo 12 Plus analysis results are activities from the effects of discussions with the Chairperson of the Bina Siwi Orphanage Foundation and various supporting data in clarifying the findings on the effectiveness of social assistance in developing human resources at the orphanage. Bina Siwi Year 20182020 with analysis results that show part of activities in the implementation of human resource management. The findings from the research show that the effectiveness of social assistance in orphanages is running effectively, which is mandated to meet the needs of life and various activities that impact development in meeting the needs and development of human resources. The discussion that emerged was represented by bringing up the ten most famous words: orphanage, development, resources, social, disability, resource, human, research, siwi, and bina. The discussion of the findings provides an overview of the research results that influence the implementation of receiving social assistance in human resources development.

\section{CONCLUSIONS \\ RECOMMENDATIONS}

AND

The effectiveness of social assistance in developing human resources at the Bina Siwi Orphanage in 2018-2020. It was concluded that the help obtained from various sources of assistance (Social Service, Community, Donors, and Volunteers) was in the form of money, necessities, motorbikes, and necessary tools that were used effectively in developing human resources at the Bina Siwi Orphanage. The effectiveness of social assistance can be seen from the activities carried out by the residents of the orphanage in creating valuable works that can increase creativity/skills that are tailored to interests and abilities, fulfillment of education, health insurance, and completion of food and clothing as well as savings to make a living urgent need.

Jurnal IImu Sosial dan Humaniora| 222 


\section{ACKNOWLEDGMENT}

Thanks to the Department of Government Affairs and Administration, Jusuf Kalla School of Government. Universitas Muhammadiyah Yogyakarta, and Bina Siwi Orphanage have supported the publication of this work.

\section{REFERENCES}

Afriansyah, A., \& Santoso, M. B. (2020). Pelayanan Panti Werdha Terhadap Adaptasi Lansia. Responsive, 2(3), 139.

https://doi.org/10.24198/responsive.v2 i3.22925

Akbar, R. R. El, \& Gunawan, R. (2016). IBM Pelatihan Multimedia Untuk Anak Anak Yatim Piatu di Panti Asuhan Hifdhul Mursalin Kota Tasikmalaya. Jurnal Siliwangi, 2(1), 81-88.

Barany, L. J., Simanjuntak, I., Widia, D. A., \& Damuri, Y. R. (2020). Bantuan Sosial Ekonomi di Tengah Pandemi COVID-19: Sudahkah Menjaring Sesuai Sasaran? Centre for Strategic and International Studies, April, 1-11. https://www.csis.or.id/publications/ban tuan-sosial-ekonomi-di-tengahpandemi-covid-19-sudahkahmenjaring-sesuai-sasaran

Creswell, J. W. (2018). Research Design: Qualitative, Quantitative, Mix Method.

Hanifah, N. (2020). Efektivitas pemberdayaan masyarakat melalui penyaluran dana bantuan baznas provinsi papua. 1(1), 42-56.

Hasan, N. F., Ilmu, S. T., Nahdlatul, T., Al, U., \& Mojokerto, H. (2017). Efektivitas Penggunaan Dana Bantuan Pendidikan (Studi Kasus pada Siswa Peserta PIP dari Keluarga Peserta PKH di SDN Jogosatru Sidoarjo). MODELING: Jurnal Program Studi PGMI, 4(1), 1-18.

I Made Oka Wirawan. (2015). Efektivitas Program Bantuan Usaha Ekonomi Produktif (UEP) Dalam Upaya Peningkatan Kesempatan Kerja dan
Pendapatan Rumah Tangga Miskin (Rtm) di Kecamatan Kerambitan. Jurnal Pendidikan Ekonomi Udiksha, $5(1), 3$.

Irsan, A. A. (2017). Implementasi Kebijakan Tentang Penyandang Disabilitas di Yayasan Wisma Cheshier dan Panti Sosial Bina Daksa Budi Bhakti Jakarta. JIPP : Jurnal IImu Politik Dan IImu Pemerintahan, 05(02), 122-139.

Irwandi. (2017). Program Pengembangan Potensi Dan Pemberdayaan Melalui Pendidikan Life Skill (Pengembangan Life Skill Penghuni Panti Asuhan AtTaqwa Muhammadiyah Kenagarian III Koto Kec. Rambatan Kabupaten Tanah Datar). Jurusan Komunikasi Dan Penyiaran Islam.

Kementrian Sosial. (2018). Efektivitas Kinerja Sumber Daya Manusia Penyelenggaraan Kesejateraan Sosial Di Daerah.

Khaira, I., Firman, F., \& S, N. (2017). Efektivitas Pendekatan Rational Emotive Behavior Therapy (Rebt) Dalam Meningkatkan Penyesuaian Sosial Anak Asuh Di Panti Asuhan Wira Lisna Padang. Bikotetik (Bimbingan Dan Konseling: Teori Dan Praktik), 1(1), 1. https://doi.org/10.26740/bikotetik.v1n1 .p1-7

Kurniawan, M. (2015). Penelitian sosial dalam rangka meningkatkan efektivitas program csr di desa segamit studi kasus pt. supreme energy. Jurnal IImiah Ekonomi Global Masa Kini, 06(01), 35-38.

Marpaung, P., \& Hulu, G. (2019). Efektivitas Pelaksanaan Pelayanan Sosial dan Pembinaan Terhadap Perilaku Anak Asuh. Jurnal Governance Opinion, 4(1), 67-84. http://jurnal.darmaagung.ac.id/index.p $\mathrm{hp} / g o v e r n a n c e o p i n i o n / a r t i c l e / v i e w / 259$

Muskhir, M. (2019). Efektivitas Pelatihan Sistem Pendingin Sebagai Upaya Peningkatan Life Skill Bagi Pemuda

Jurnal IImu Sosial dan Humaniora | 223 
PSAABR Budi Utama Lubuk Alung Kabupaten Padang Pariaman. 5(2), 45-52.

Nica, C. (2017). Efektivitas Pembinaan Sumber Daya Manusia Dalam Membangun Keberhasilan Anak. Program Studi Kesejateraan Sosial.

Nuskhiya, A. (2015). Efektivitas Pemberdayaan Masyarakat Dalam Pengentasan Kemiskinan Pada Program Gerdu Kempling Di Kelurahan Kemijen Kota Semarang. Teknik Perencanaan Wilayah Kota, 4(2), 253-268.

Putri Diah Qashdinad, A. (2018). Pentingnya Peran Kelekatan Teman Sebaya Dalam Konsep Diri dan Kecerdasan Emosi Remaja di Panti Asuhan di Kota Banda Aceh. Jurnal PKS, 1.

Rahim, A. (2019). Abdur Rahim, Analisa Dan Perancangan Sistem Informasi Pembinaan Panti Asuhan Pada Panti Asuhan Muhammadiyah Tembilahan 44. Jurnal SISTEMASI, 2(3), 44-55.

Ristyawati, A. (2020). Efektifitas Kebijakan Pembatasan Sosial Berskala Besar Dalam Masa Pandemi Corona Virus 2019 oleh Pemerintah Sesuai Amanat UUD NRI Tahun 1945. Administrative Law and Governance Journal, 3(2), 240-249.

https://doi.org/10.14710/alj.v3i2.240249

Roja, M. L. (2020). Kebijakan Pendidikan Anak Terlantar Di Panti Asuhan ST. Louis De Monfort Kota Kupang. SosioEdu: Sociological Education, 1(1), 1-10.

Samsudin, Muhamad, Aji Ratna Kusuma, S. D. (2019). Faktor-Faktor Yang Berpengaruh Terhadap Efektivitas Penyaluran Bantuan Sosial Di Bagian Sosial Sekretariat Daerah Kabupaten Kutai Timur. Jurnal Administrative Reform, 2(1), 74-87. http://ejournals.unmul.ac.id/index.php/JAR/ar ticle/view/501
Setiawan, R. I. (2016). Pengembangan Sumber Daya Manusia Di Bidang Pariwisata: Perspektif Potensi Wisata Daerah berkembang. Jurnal Penelitian Manajemen Terapan (PENATARAN), 1(1), 23-35.

Setiyawan. (2019). Pengelolaan Sumber Daya Manusia yang Handal. Journal of Chemical Information and Modeling, 53(9), 1689-1699.

Setiyawati, E., Raharjo, S. T., \& Fedryansyah, M. (2018). Proses Pelayanan Sosial Di Rumah Yatim AtTamim Kecamatan Cileunyi Kabupaten Bandung. Prosiding KS: Riset \& PKM, 3, 135.

Sitepu, A. (2016). Analisis Efektifitas Kelompok Usaha Bersama Sebagai Instrumen Program Penanganan Fakir Miskin Efectivity Analysis Collective Business Group ( Cbg ) As An Instrument Abstrak Hingga Saat Ini , kemiskinan merupakan kendala utama dalam peningkatan kesejahtera. Sosio Informa, Vol. 2, No, 53-68.

Sufi, D. K., \& Mujahiddin, M. (2020). Peranan Panti Asuhan Putri Aisyiyah Kabupaten Aceh Singkil dalam Meningkatkan Kemandirian Anak. Jurnal Intervensi Sosial Dan Pembangunan (JISP), 1(1), 1-16. https://doi.org/10.30596/jisp.v1i1.4372

Sulaeman, M. (2018). Efektifitas Pelatihan Keterampilan Berusaha Dan Bantuan Stimulan Usaha Ekonomis Produktif Terhadap Pengentasan Kemiskinan (Studi Kasus Di Kota Banjar). Jurnal Terapan Abdimas, 3(1), 28. https://doi.org/10.25273/jta.v3i1.2164

Sunarsi, D. (2018). Pengembangan Sumber Daya Manusia Strategik \& Karakterisrik Sistem Pendukungnya: Sebuah Tinjauan. Jurnal IImiah MEA (Manajemen, Ekonomi, \& Akuntansi), 2(3), 178-194.

Vampa, D. (2017). From National to SubNational? Exploring the Territorial Jurnal IImu Sosial dan Humaniora | 224 
Herpita Wahyuni, Zuly Qodir | The Effectiveness of Social Assistance in the Development of Human Resources in Bina Siwi 2018-2020

Dimension of Social Assistance in Italy. Journal of Social Policy, 46(2), 269-289.

https://doi.org/10.1017/S00472794160 00659

Vandenbroucke, F., Luigjes, C., Wood, D. J., \& Lievens, K. (2017). Institutional Moral Hazard in the Multi-Tiered Regulation of Unemployment and Social Assistance Benefits and Activation - A Summary of Eight Country Case Studies. In SSRN Electronic Journal. https://doi.org/10.2139/ssrn.2779579

Zamawe. (2015). The implication of using NVivo software in qualitative data analysis: Evidence-based reflections. Malawi Medical Journal, 27(1). 